\title{
Firm Financial Status and Investment Behaviour: Evidence from Manufacturing Firms in Nigeria
}

\author{
Alarudeen Aminu* \\ Isiaka Akande Raifu ${ }^{* *}$
}

\begin{abstract}
The study examines firm's investment behaviour sensitivity to cash flow before, during and after the recent global financial crisis using the data of 28 firms listed on the Nigerian Stock Market during the period from 2001 to 2012. The contribution of the study to the existing literature rests on using financial crisis as basis for classifying firms as either financially constrained or unconstrained. Employing the panel data and instrumental variable estimation techniques, the study finds that firms' investment behaviour sensitivity to cash flow was higher during the financial crisis than before or after the financial crisis. In other words, Nigerian firms were highly financially constrained during the last financial crisis.
\end{abstract}

Keywords: firms' investment; cash flow; Tobin's q, panel data analysis; instrumental variables

JEL Classification: C33, C36, G31

\section{Introduction}

The goal of any firm under a neoclassical setting is to maximise profit subject to various constraints in the process of production. One of these constraints is the ability of firms to finance their investment. However, the financial status of firms in relation to their investment has generated a lot of heated debates in the financial literature. Beginning from the theoretical proposition of Modigliani-Miller (1958), under the assumption of perfect and complete market, it was posited that corporate financing and investment decision do not depend on each other. This implies that the financial status of a firm is not relevant to its investment decision. In this case, both internal and external finances are regarded as perfect substitutes.

\footnotetext{
* Alarudeen Aminu is a lecturer in the Department of Economics, Faculty of Economics, University of Ibadan, Ibadan, Nigeria.

** Isiaka Akande Raifu is doctoral student in the Department of Economics, Faculty of Economics, University of Ibadan, Ibadan, Nigeria.
} 
The real life situation, however, shows that the existence of asymmetric information in the financial markets results in market imperfection and this makes the substitutability of external finance for internal finance impossible. Financial market imperfections, particularly in the capital market, manifest in different forms such as increase in transaction costs, agency problems and costs of financial distress. ${ }^{1}$ These make the cost of obtaining external finance such as bonds or equity very high. Consequently, firms have to rely on their internally generated revenues such cash flow and retained earnings. Firms rely on internally generated revenues (cash flow) because internal funds are cheaper compared with external funds. This argument in the literature is the genesis of the concept of financial constraint and the sensitivity of the firm's investment decision to its cash flow in financial economics. Conceptual definition posits that a firm is financially constrained if it faces a wedge between the internal and external costs of funds. ${ }^{2}$

In order to examine firms' investment-cash sensitivity, several theoretical and empirical studies have been conducted, especially in advanced countries. The first major theoretical exposition on the relationship between the financial status (cash flow) and investment began with the work of Meyer and Kuh (1957). However, Fazzari, Hubbard and Petersen (1988) pioneered the empirical research on the examination of investment-cash flow sensitivity in the presence of market imperfections. In their work, they discovered that firms' investment indeed is sensitive to their cash flow fluctuations and that most financially constrained firms have greater investment-cash flow sensitivity than the least constrained firms. ${ }^{3}$ On the other hand, Kaplan and Zingales (1997) and Cleary (1999) finding differs from the one of Fazzari, Hubbard and Petersen. They found that the investment decisions of the least financially constrained firms are the most sensitive to the availability of cash flow.

Despite the huge volume of literature for advanced countries on the sensitivity of investment to the firm's internal funds, there is still a dearth of such research for developing countries, especially for Africa and Nigeria in particular. Notable studies geared towards addressing the issue of sensitivity of corporate investment to finance in Nigeria were done by Ariyo and Adelegan (2008) and Adelegan (2009). ${ }^{4}$ The results from both studies showed that financial factors are significantly relevant to the firm's investment behaviour in Nigeria. However, both studies were done using data before the financial crisis (1984-2000 and their studies did not address the issue financial constraint in relation to the financial crisis. This paper, therefore, seeks to fill this gap in the literature, particularly for Nigeria. Specifically, the paper focuses on the sensitivity of the firm's investment to cash flow before, during and after the financial crisis. Since economic environment is dynamic rather than static, this kind of study is not only crucial but also justifiable against the background the e impact of the recent global financial crisis on the financial sector as manufacturing firms sought funds to finance their investments. 
To achieve the above objective, three periods are distinguished as follows: before the financial crisis, during the financial crisis and after the financial crisis. We assumed that firms are likely to be financially constrained during the financial crisis than before and after the crisis. Besides, we also employed the q-cash flow model. The q-cash flow model specified was estimated using panel data of 28 manufacturing companies listed on the Nigerian Stock Exchange spanning the period 2001-2012. Apart from applying Ordinary Least Squares (OLS) with fixed effect and random effect techniques, we also used Instrumental Variable and Generalised Method of Moment estimation techniques to address the endogeneity problem that OLS fails to capture in empirical studies. Our results show that the firms' investment was more sensitive to cash flow during financial crisis compared with the period before and after financial meltdown. This implies that firms were more financially constrained during the financial crisis.

The rest of the paper is organised as follows. Section two reviews existing literature covering the relationship between corporate investment decision and finance. Section three presents the research methodology and data source and description. In Section four, the analysis and interpretation of findings are discussed. Section five concludes the study.

\section{Literature Review}

In this section an attempt is made to review the extant literature in this study. Specifically, the review is disaggregated into three, namely: theoretical review, methodological review and empirical review.

\section{Theoretical Literature Review}

There are several theories of investment. The first theory of investment known as the accelerator principle dates back to the work of early economists such as Carver (1903), Aftalion (1909), Bickerdike (1916) and Clerk (1917). Specifically, the accelerator principle states that, given flexible prices and partial adjustment towards the desired capital stock, each period's investment depends on prices of output and interest rate (cost of capital). This means that investment and output are positively linked. Thus, as the demand for output increases due to increase in consumer's income, the investment will increase in the same proportion. However, the accelerator principle has been criticised on the ground that an increase in demand cannot automatically translate to investment. This is because some capital acquired in the past may be lying idle and need to be put to use to produce more output to meet the increase in demand instead of acquiring new one. 
Keynesian theory of investment, on the other hand, focuses on the Net Present Value (NPV) of investment. The theory, specifically, states that investments are made until the present value of expected future revenues at the margin is equivalent to the opportunity cost of capital (Keynes, 1936). This implies that investments are made until the net present value of investment is equal to zero. However, the Keynesian theory of investment has also been criticized on the ground that it fails to capture the optimal adjustment of capital towards equilibrium.

On the part of neoclassical economists, the first theory of investment was developed by the duo of Modigliani and Miller in 1958 in what was described as the irrelevance theory of investment. According to this theory, which is propounded under the assumption of perfect capital market where information is fully available, firm's investment is independent of sources of financing it. The second neoclassical theory of investment was developed and formalised by Jorgenson (1967). The theory takes into consideration the optimal capital, which Keynesian theory failed to account for. According to Jorgenson, a profit maximisingfirm will invest in each period until the return (profit) yields optimal capital. Despite the fact that the theory takes into consideration the issue of optimal capital, it, however, fails to capture the adjusted cost of capital.

In order to account for the adjustment of the cost of the capital, the Q-theory of investment was formulated by the duo of Brainard and Tobin in 1968. According to them, investment is made until the market value of assets is equal to the replacement cost of assets. This theory is arrived at by adding a marginal adjustment cost function to the profit function of the Jorgenson's neoclassical theory of investment. By doing this, the financial policies can influence the aggregate demand through the valuation of firm's physical assets to their replacement cost.

One central shortcoming of these theories of investment is that they did not account for the role of profit or internally generated revenue (cash flow) as a determinant of investment. However, the cash flow theory of investment stipulates that the current and the past profits are a good proxy for future profit expectation, which in turn determines investment (Klein, 1958). Thus, given the change in tax treatment of depreciation, profits plus depreciation provide a better measure of firm's cash flow and this determines investment in the presence of risk and imperfect capital markets which raise the cost of external funds more than the internal funds (Duesenberry, 1958).

\section{Methodological Literature Review}

The methodologies usually adopted in the literature to examine investment-cashflow sensitivity are examined in this subsection. These methodologies are broadly classified into two, namely: sample classification methods and estimation technique methods. 
There are several ways to classify firms into either constrained or unconstrained. Beginning with the work of Fazzari et al, (1988), firms are classified as either low-dividend-paying-out or high-dividend -paying-out using the prevalent dividend pay-out ratio. Other criteria that have been used include: bond rating (Whited, 1992); commercial paper rating (Calomiris, Himmelberg, and Wachtel, 1995); the age of the firm (Oliner and Rudebusch, 1992); the size of the firm (Devereux and Schiantarelli, 1990); Sembenelli Rondi, Schiantarelli and Sack, 1993; Carpenter, Fazzari, and Petersen, 1994); Erickson and Whited, 2000); bank and group or industrial affiliation (Schaller, 1993; Chirinko and Schaller, 1995; Hoshi, Kashyap, and Scharfstein, 1991); agency problems and concentration of ownership (Oliner and Rudebusch 1992; Ng and Schaller, 1991); legal environment (Marhfor, M'Zali and Cosset, 2012); and growth opportunities (Almeida and Campello, 2007).. These criteria have, however, been criticized because they fail to take into account the fact that firms may transit between states in which they face binding financial constraints and states in which they do not. To take account of this shortcoming, Ariyo and Adelegan (2008); Hobdari, Jones and Mygind (2009) used switching regression method while Cleary (1999) constructed Z-score financial constraint beginning from discriminant analysis that allows the firm to transit over the year from financially constrained state to financially unconstrained state.

With respect to estimation techniques, Ordinary Least Squares (OLS), which takes into account firm and time specific effects, otherwise known as Panel Data Estimation, has been a major estimation technique used to investigate or examine investment-cash flow sensitivity (Fazzari, et al, 1988). However, the OLS estimation technique has been criticized for lack of power to tackle the measurement errors embedded in one of the modelled variables, particularly Tobin's q. This is because when Tobin's q is measured wrongly, its coefficient obtained from OLS estimators becomes biased and has a low explanatory power, thus creating an endogeneity problem (Baum and Thies, 1997). To address the endogeneity problem, other estimation techniques proposed in the literature include: the higher-order moment due to Erickson and Whited (2000), the instrumental variables approach (Griliches and Hausman, 1986; Baum and Thies, 1999) and its extended version by Biorn, (2000) and Generalised Moment Method estimator suggested by Arellano and Bond (1991).

\section{Empirical Literature Review}

The literature is awash with empirical studies on investment-cash flow sensitivity. In this review, the results are grouped broadly into two; based on those who obtained similar results and those who obtained different results.

For the studies with similar results, the reference point to begin with is the work of Fazzari et al, (1988). They used USA firm level data covering the period from 1969 to 
1984. Firms were categorized according to whether they were financially constrained or not based on dividend payout, size, capital structure and other characteristics that determine whether they were more sensitive to availability and supply of internal funds. Their empirical results showed that investment was more sensitive to cash flow, especially for firms with low dividend payout ratios and less sensitive for firms that had high dividend payout ratios. Several studies have followed the methodology adopted by Fazzari et al,(1988) though, with the adoption of different criteria for categorizing firms as either financially constrained or not to arrive at similar results.

For instance, Baum and Thies (1999) examine the econometric critique of investment-cash flow sensitivity. In order to do this, they use the data of 98 large USA manufacturing that cover a period of 1977 to 1983. After controlling for research and development in the investment-cash flow equation, their results show that research and development expenditures are capitalised, that is, enters the model with a coefficient that is highly significant and it is statistically significant as cash flow in the traditional cash flow-Q model. Besides, after classifying cash flow into expected and unexpected, they equally find that both have different effects. They find that the coefficients of unexpected cash flow (UCF) and expected cash flow (ECF) are higher for firms classified as high cost of external finance than those that are less. Besides, they also find that the effects of $\mathrm{Q}$ are much more evident in firms facing low costs of external finance.

Hubbard, Kashyap and Whited, (1995) applied Euler equation model to examine the relationship between internal finance and firms' investment. The research was based on the hypothesis of frictionless capital market. Total samples of 428 firms were used and the data covered the period from 1976 to 1987. Their results show that neoclassical hypothesis of frictionless market can be rejected for the low dividend pay-out subsample of firms while it fails to reject the hypothesis for high dividend pay-out subsample of firms.

Chirinko and von Kalckreuth, (2002) investigate the relationship between firm's investment decisions and financial status in Germany. The data used in their study were extracted from BundesBank Database and cover a period of 1988 to 1997 for 6408 firms with data point of 44,345. They used several estimation techniques to critically examine the palpable relationship that exists between the firm's investment and its financial status. Their results (based on OLS estimation) show that financially constrained firms are less sensitive to cash flows. The results from GMM (IV) (which is meant to address the problem of endogeneity between the regressors and regressand) show that the coefficient of cash flow is lower compared with those of OLS which confirms the presence of positive correlations between investment and cash flow. Since the coefficients are now positive, they show that constrained firms' investment is sensitive to cash flow. In conclusion, based on firms' credit worthiness classification, they found that constrained firms are more sensitive to cash flow. 
Carpenter and Guariglia, (2003) investigate cash flow, investment and investment opportunities using UK panel data in which 693 UK firms with 6308 annual data observations were used, covering the period from 1983 to 2000. After including contracted capital expenditure to capture information about opportunities available only to insiders and thus not included in $\mathrm{Q}$, they find that power of cash flow falls for large firms, but remains unchanged for small firms though still positive.

Alti, (2003) studies the sensitivity of investment to cash flow when financing is frictionless. He uses simulated data covering the period from 1969 to 1984. The overall results indicate that frictionless benchmark accounts for the magnitude of the investment-cash flow sensitivity and the pattern it exhibits. Specifically, he observes that investment is sensitive to cash flow for all firms, even after controlling for Tobin's Q. Also, the sensitivity is however higher for young, small firms with high growth and low dividend pay-out ratio and finally Tobin's $Q$ is found to be a more noisy measure of the investment opportunity for young firms with high growth rates but not for old firms.

Mizen and Vermuelen, (2005) examine the relationship between corporate investment and cash flow sensitivity with the aim of knowing the driver of the observed relationship between corporate investment and cash flow. The sample of firms selected contains 378 firms from UK and 145 German firms. The data used cover 19931999 period. For all the possible drivers of the sensitivity of investment to cash flow such as firm size, industrial structure and credit worthiness of firms, only the credit worthiness of firm drives the sensitivity of investment to cash flow in both UK and Germany.

Almeida and Campello (2007) work on financial constraints, asset tangibility and corporate investment. The study used the universe manufacturing firms (SICs 20003999) over the 1985 to 2000 period. Their results show that asset tangibility positively affects the cash-flow sensitivity of investment in financially constrained firms but not unconstrained firms.

Adelegan and Ariyo, (2008) examine capital market imperfections and corporate investment behaviour using a switching regression approach and panel data for Nigerian manufacturing firms. A total of 85 manufacturing firms are considered covering 14 industries. The data covered the period from 1984 to 2000. Adopting Switching Regression which divides the firms into low and high premium regimes, they discover that investment in Nigeria responds to financial variables. Specifically, Q plays an important role in determining investment while cash flow in its effect differs across the firms' classifications.

Adelegan, (2009) examines the relationship between investment, financial factors and cash flow using the same number of firms and data coverage as obtained in Adelegan and Ariyo, (2008). It is found that that financial factors are important for investment in all firms. However, the degree of importance of financial factors is not evenly distributed according to the criteria considered (age, size and industry classification). 
Hobdari, Jones and Mygind, (2009) investigate the capital investment and determinants of financial constraints in Estonia using a panel data of Estonia companies over the period from 1993 to 2002 . Their results show that both output and cash flow are both positively related to investment. In other words, output and cash flow are important variables in determining investment. In addition, their results show that financially constrained firms are sensitive to the availability of internal finance, while financially non-constrained firms are more responsive to future growth opportunities. Finally, firms whose ownership structures are dominated by insiders face a higher probability of being financially constrained and display higher sensitivity to availability of internal finance.

Bond and Söderbom, (2010) research into the conditional investment-cash flow sensitivities and financing constraints based on simulated data for 2000 firms observed for 14 periods. The results from OLS regression show that with no cost premium for external finance, the coefficients of cash flow variable do not significantly differ from zero while the coefficient on average $q$ is insignificantly different from the reciprocal adjustment cost parameter. However, with increasing cost premium for external fund, that is new equity, the coefficient of cash flow variable is set to be positive and significantly different from zero and increase monotonically as the cost of the new equity increases. Similar results were obtained when the new source of external finance was introduced, debt with a fixed interest rate and increasing interest rate.

Lewellen and Lewellen, (2011) examine the new evidence of investment and cash flow using USA firms' data covering the period from 1971 to 2009. Having controlled for firm's investment opportunity, they find that cash flow is strongly related to investment for firms that are likely needed to access external finance.

Annabi, et al, (2012), work on the financial constraints, information asymmetry and firm investment in Tunisia. They a data set of 394 firms during the period from 2001 to 2008.. They find that cash flow representing the financial constraint is positively related to firm investment. Also, while the firm size does not influence investment behaviour while debt, bank affiliation (proxied by dummy variable) and the capacity for self-financing affect investment.

Marhfor, et al, (2012) work is based on firm's financing constraints and investment-cash flow sensitivity: evidence from country legal institutions. The study makes use of data of 44 countries (developed and emerging countries) over the period 19952007. Their results suggest that the investment decisions of companies originating from countries that provide strong legal protection to minority investors are less sensitive to the availability of cash flow. Further, transparent companies exhibit lower investment-cash flow sensitivity in comparison to opaque companies. Finally, additional analysis shows negative association between their proxy of stock price information and investment cash-flow sensitivity. Thus, the overall results show that firms that are supposed to be financially constrained exhibit greater investment cash flow 
sensitivity having classified firms into constrained and unconstrained based on the stock price informativeness.

Despite the fact that a large number of empirical studies supported the Fazzari et al results, there are, however, a battery of empirical studies that contradict their findings. These studies suggest that the observed investment-cash flow sensitivity might be driven by increased investment opportunities or by endogeneity bias in the underlying investment equation. For instance, Kaplan and Zingales, (1997) conducted a study using 49 US low dividend firms identified by Fazzari, et al., (1988) as being financially constrained from 1970 to 1984 with the aim of examining whether investment-cash flow sensitivity provides a useful measure of financial constraints or not. Several model specifications were formulated to test the robustness of investment-cash flow sensitivity based on the classification of firms as constrained or unconstrained using qualitative information extracted from company's annual reports. Their results showed that unconstrained firms exhibited high investment-cash flow sensitivity while constrained firms exhibit low investment-cash flow sensitivity. They equally found that those firms classified as less financially constrained exhibited a significantly greater investment-cash flow sensitivity than those firms classified as more financially constraints.

Besides the Kaplan and Zingale results, Cleary (1999) research also revealed that the investment decisions of firms with high creditworthiness were significantly more sensitive to the availability of internal funds than firms with less creditworthiness. Cleary had examined the relationship between firm investment and finance status using a sample of 1,317 USA manufacturing firms with data covering the period from 1987 to 1994.

There are other studies that reported a negative relationship between investment and cash flow (Bhagat, et al, 2006; D'Espallier and López-Iturriaga, 2009 and Jiming, et al, 2010) while a number of studies observed that the relationship between firms' investment and cash flow is not monotonic but U-shaped, otherwise known as U-shaped hypothesis (Cleary, Povel, and Raith, 2007; Kozhan and Pal, 2008; Bushman, Smith and Zhang,; 2011).

The foregoing empirical results show that corporate investment-finance relationship remains inconclusive, thus necessitating the need for further examination of the relationship, especially using data of a developing country like Nigeria.

\section{Methodology, Estimation Techniques and Data Source and Measurement}

In this section, the methodology employed to examine the relationship between firms' financial status and investment decision is presented. The section is broadly divided into three: the criteria used to select firms as either constrained or unconstrained, the 
methods of estimation and the specification of the model, data source and description. These are discussed one after the other as follows:

\section{Sample Classification Criteria}

We classified firms into either financially constrained or financially unconstrained based on the 2008 global financial crisis. The period of analysis is divided into three as follows: before the financial crisis, during the financial crisis and after the financial crisis. The a priori expectation is that firms will be financially constrained during the financial crisis, but less financially constrained before and after the financial crisis.

\section{Model Specification}

The model employed in this study is specified following the approach of Fazzari et al (1988) and Adelegan (2009) in which empirical research on financial constraints and firms' investment is based on the reduced form of q-cash flow investment model. In this case, variables that measure financial constraints are added to the basic reduced form equation of investment. Thus, it is imperative to include the measure of internal financing sources and the standard measure of internal financing source commonly used in the literature is cash flow. Including the cash-flow in the q-model of investment gives the following model.

$$
\left(\frac{I}{K}\right)_{i t}=\alpha_{i}+\beta q_{i t}+\gamma\left(\frac{C F}{K}\right)_{i t}+\delta\left(\frac{X}{K}\right)_{i t}+\varepsilon_{i t}--------(1)
$$

\section{Where}

$\mathrm{I}_{\mathrm{it}}=$ investment expenditure by firms

$\mathrm{K}_{\mathrm{it}}=$ capital stock proxied by total asset

$\mathrm{q}_{\mathrm{it}}=$ Tobin's qi5

$\mathrm{CF}_{\text {it }}=$ cash flowv

$\mathrm{Xit}=$ other control variables included in the estimation6

$\alpha_{\mathrm{i}}=$ the normal value of $\left(\frac{\mathrm{I}}{\mathrm{K}}\right)$ for the ith firm

$\varepsilon_{\mathrm{it}}=$ the error term

In the model above, our variable of interest is cash flow which is used as a proxy for firms' internal net worth. One expects that the more the severity of information asymmetry and agency cost problems faced by firms, the higher will be the cost of external finance and the greater the sensitivity of firms' investment to cash flow. Thus, it is expected that the estimated cash flow coefficient will be significantly and 
positively related to investment which in previous studies is taken as a signal of financial constraint. On the other hand, an insignificant estimated cash flow coefficient is considered as evidence that firms are financially unconstrained. Suffice to say that the model above is scaled by capital stock to avoid the problem of heteroskedasticity (Adelegan, 2009).

\section{Estimation Techniques}

The estimation technique employed in this study is Ordinary Least Square (OLS) which incorporate the firms' fixed effect. However, following the extant literature, instrumental variable techniques are equally implemented especially in the moulds of, Two Stage Least Squares and Generalised Methods of Moment to address the observed issue of endogeneity problem.

\section{Data Sources and Measurement}

This study uses a total number of 28 manufacturing firms listed on the Nigerian Stock Exchange. The firms are chosen because they have relevant data required for the analysis. Apart from this, the companies selected are spread across 9 sectors of the economy/stock market, namely: Agriculture, Conglomerate, Construction/Real Estate, Consumer Goods, Healthcare, Industrial Goods, Oil and Gas, Printing and Publishing and Services. Data used for the study cover the period from 2001 to 2012 and they are secondary data extracted from the annual reports of the firms and Securities and Exchange Commission (SEC). The choice of sample period is important because during these years, the world witnessed the most recent financial crisis that led to the collapse of some stocks in the world including Nigeria.

The measurement of the data used in this study is presented $\mathrm{n}$ the following Table 1.

Table 1: Data Measurement

\begin{tabular}{|l|l|}
\hline Variables & Measurement or Computation \\
\hline Investment & Capital expenditure/Investment in fixed asset \\
\hline Tobin's q & Market value of equity minus total liability divided by total asset \\
\hline Cash flow & Profit after tax plus depreciation \\
\hline Leverage ratio & Total debt/liability divided by total equity \\
\hline Profit after tax & Profit after tax \\
\hline Sales & Log of turnover \\
\hline
\end{tabular}

Source: Compiled by Authors 


\section{Presentation of Empirical Results}

In this section, the results of the investment-cash flow sensitivity are presented. Specifically, the results are presented under three headings, namely: Investment-cash flow sensitivity before the financial crisis, investment-cash flow sensitivity during the financial crisis and investment-cash flow sensitivity after the financial crisis.

\section{Investment-Cash Flow Sensitivity Results before Financial Crisis}

This section focuses on investment-cash flow sensitivity before the financial crisis. The analysis is predicated on the assumption that firms are less financially constrained before the financial crisis.

First, the OLS panel results are presented in the 2nd, 3rd and 4th columns of Table 2 below. The results, based on fixed effect estimation using Hausman selection criterion, show that cash flow has a significant negative effect on the firm's investment before the financial crisis. On a priori ground, a significant negative or insignificant positive coefficient of the investment-cash flow shows that investment is less sensitive during this period. The rationale for this may be attributed to the fact that firms may have different sources of securing funds for their investment during this period. Besides this, Tobin's q has a negative and insignificant relationship with investment. However, leverage ratio has a positive and significant effect on investment. However, profit after tax and sales exhibit negative and insignificant effects on investment. This shows that firm's investment does not depend on its internal cash flow, but on its leverage ratio.

Colum 5 presents the results of Two Stage Least Squares estimation with three lags of Tobin's q employed as instruments. In this case, Sargan Chi2 test and Basmann chi2 are used for the over-identification test of all instruments. The Sargan Chi2 test and Basmann Chi2 test results show that the instruments used are not over-identified. The results obtained from this estimate are akin to the one obtained from OLS panel estimates as cash flow has a negative insignificant effect on firms' investment, thus confirming the low sensitivity of the firm's investment to cash flow. Both Tobin's q and leverage ratio have a positive effect on investment, however, only the coefficient of the leverage ratio is statistically significant at the $5 \%$ level.

In column 6, the results relate to Generalized Methods of Moment estimate using three lags of both dependent and independent variables as instruments. Here, Hansen's J Chi2 is used for testing the over-identification of the model. The results of Hansen's J test value of 7.649 ( 0.9068 ) show that the model is not over-identified. The results also show that Tobin's q is negatively and significantly related to investment. Profit after tax as well is insignificantly and negatively related to investment. However, cash flow, leverage ratio and sales are positively linked with investment albeit not 
statistically significant. This results show that investment is less sensitive to cash flow before the financial crisis.

Our results corroborate the findings in the existing literature that we reviewed (Fazzari, et al., 1988, Adelegan and Ariyo, 2008, Adelagan, 2009). This is because before the financial crisis firms may not be financially constrained as they have many options in terms of raising funds to finance their capital projects. Thus, their investment decisions may not depend on their cash-flow or internally-generated funds. Besides, it will be easy for firms to raise funds in the financial market, either through public subscription or borrowing if the financial sector does not face any major crisis like the global financial crisis of 2007-2009.

Table 2: Investment-Cash Flow Sensitivity before Financial Crisis Dependent Variable: Investment

\begin{tabular}{|c|c|c|c|c|c|}
\hline Column 1 & Column 2 & Column 3 & Column 4 & Column 5 & Column 6 \\
\hline Variables & $\begin{array}{c}\text { OLSPA (Pooled } \\
\text { Analysis) }\end{array}$ & Panel with FE & Panel with RE & IV(2SLS)3L & IV (GMM) \\
\hline Constant & 0.000207 & 0.0000736 & $0.000197 * *$ & $0.000286^{* * *}$ & $0.000159 * * *$ \\
\hline Tobin's q & -0.000056 & -0.000073 & -0.0000556 & 0.0000716 & $-0.000105^{* *}$ \\
\hline Cash flow & 0.00883 & $-0.645^{* *}$ & -0.107 & -0.417 & 0.103 \\
\hline Leverage ratio & $0.000136^{* *}$ & $0.000269 * * *$ & $0.000157 * * *$ & $0.000348^{* *}$ & 0.00000588 \\
\hline Profit after tax & -0.170 & 0.316 & -0.0567 & -0.0230 & -0.106 \\
\hline Sales & -0.0171 & 0.0636 & -0.0104 & -0.0856 & 0.0223 \\
\hline R-Square & $0.0594(5.94 \%)$ & $0.0264(2.64 \%)$ & $0.0569(5.69 \%)$ & $0.1149(11.49 \%)$ & $0.0060(0.60 \%)$ \\
\hline F-Statistics & $1.90(0.0984)$ & $2.51(0.0335)$ & $8.94(0.1115)$ & $9.93(0.0774)$ & $14.57(0.0124)$ \\
\hline Hausman Test & & \multicolumn{2}{|c|}{$12.27(0.0313)$} & & \\
\hline \multicolumn{6}{|c|}{$\begin{array}{l}\text { Sargan (score) chi2 }(2)=1.940(p=0.3790) \\
\text { Basmann chi } 2(2) \quad=1.765(p=0.4137) \\
\text { Instrumented: Tobin's } q \\
\text { Instruments: Tobin's } q(3 \text { lags }) \\
\text { Hansen's J chi2 }(14)=7.650(p=0.9068) \\
\text { Instrumented: Tobin's } q \\
\text { Instruments: Cash flow (3lags, ) leverage ratio }(3 \text { lags }) \text { profit after tax (3lags) sales (3lags) and Tobin's } q(3 \text { lags }) \text {. } \\
\text { Note: } * * *, \text { and } * * *, \text { denote significance at } 10 \%, 5 \%, \text { and } 1 \%\end{array}$} \\
\hline
\end{tabular}

Source: Computed by the authors from the Data obtained from Companies' Annual Reports using STATA 12

\section{Investment-Cash Flow Sensitivity Results during Financial Crisis}

The results of analysis of investment-cash flow sensitivity during the financial crisis are presented in Table 3. We first present the results of OLS panel estimates. However, we analyse the results of random effect here because of the insignificant Hausman test. Thus the random effect is selected based on its higher R-square estimate compared with fixed effect R-square estimate. From the Table (see column 4), the results 
show that cash flow is highly positively and significantly linked with investment with a coefficient of 1.886. This implies that during the financial, crisis cash flow was very crucial to firm investment. The high sensitivity of investment to cash flow during the financial meltdown can be attributed to the inability of firms to raise funds from external sources such as banks, money market, capital market and the likes which were also experiencing the negative effects of the financial crisis. Also, leverage ratio and sales also have a positive and significant impact on the firm's investment decision with coefficients of 0.00026 and 0.108 respectively. This implies that investment will increase as the firms are favourably leveraged and sell more of their products. However, Tobin's q has a negative and insignificant effect on investment in Nigeria as during the financial crisis, firm's profit after tax depressed investment. This may be due to the fact that firms may not want to invest their meagre profits in an uncertain business environment.

The results of Two Stage Least Squares in Table 3 in column 5 show that investment is highly sensitive to cash flow. Specifically, the coefficient of investment-cash flow sensitivity is 2.232 . The other explanatory variables, Tobin's q, leverage ratio, profit after tax and sales, have a negative insignificant impact on the firm's investment. In order to determine whether the instrument used is over-identified, Sargan and Basmann Chi2 tests are carried out. The results of Sargan and Basmann Chi2 test values of 4.278 and 4.029 respectively, with the probability values greater 5\% show that the instruments used are not over-identified.

The results from the GMM estimation in column 6 show that though cash flow is positively sensitive to firm investment, it is however not statistically significant. Besides this, leverage ratio is positively and significantly related to investment with a coefficient of 0.00017. Sales also have a positive but insignificant influence on investment. However, Tobin's q and profit after tax during the financial crisis negatively and insignificantly determine investment. The Hansen's J Chi2 test value of 11.631 with the probability value greater than $5 \%$ show that the instruments used are not over-identified.

In summary, it is found that investment-cash flow sensitivity is high during the financial crisis. This implies that investment is highly responsive or sensitive to cash flow generated by firms during the financial meltdown in Nigeria. The results are in line with the results obtained by Blalock, Gertler and Levine (2007), Campello, Graham and Harvey (2009) and Khramov (2012), La Rocca, Stagliano and Laquir, (2016), Drobetz, et al., (2014). For instance, Khramov (2012) observes that the share of physical capital in assets has a strong influence on investment-cash flow sensitivity, which decreased substantially after the financial crisis when banks changed their expectations about the value of assets on the firms' balance sheet. Similarly, La Rocca, Stagliano and Laquir, (2016) concludes that investment was sensitive to cash flow during the financial crisis of 2008. Drobetz et al., (2014) finds that financially weak firms were more affected when compared with the financially-healthy firms. 
Specifically, they show that the financial crisis of 2007-2009 affected both financing and investment activities of financial week firms and healthy firms had a minor investment reduction due to their financial flexibility.

Table 3: Investment-Cash flow Sensitivity during Financial Crisis Dependent Variable: Investment

\begin{tabular}{|c|c|c|c|c|c|}
\hline Column 1 & Column 2 & Column 3 & Column 4 & Column 5 & Column 6 \\
\hline Variables & $\begin{array}{c}\text { OLSPA (Pooled } \\
\text { Analysis) }\end{array}$ & Panel with FE & Panel with RE & IV(2SLS) & IV (GMM) \\
\hline Constant & -0.000209 & $-0.000564 * * *$ & $-0.000459 * *$ & -0.000123 & 0.000119 \\
\hline Tobin's q & 0.0000331 & -0.0000142 & -0.0000124 & -0.000076 & -0.000107 \\
\hline Cash flow & $2.406^{* * *}$ & $1.777 * * *$ & $1.886^{* * *}$ & $2.232 * * *$ & 0.469 \\
\hline Leverage ratio & 0.00000911 & $0.000296^{* *}$ & $0.000255^{* *}$ & -0.0000206 & $0.000171^{* * *}$ \\
\hline Profit after tax & $-1.243^{* *}$ & $-1.684 * * *$ & $-1.624 * * *$ & -0.638 & -0.461 \\
\hline Sales & -0.0251 & $0.153^{* *}$ & $0.108^{*}$ & -0.0155 & 0.00718 \\
\hline R-Square & $0.3110(31.10 \%)$ & $0.2204(22.04 \%)$ & $0.2478(24.78 \%)$ & $0.2970(29.70 \%)$ & $0.0540(5.40 \%)$ \\
\hline F-Statistics & $6.50(0.0000)$ & $11.83(0.0000)$ & $65.74(0.0000)$ & $31.13(0.0000)$ & $9.97(0.0760)$ \\
\hline Hausman Test & & \multicolumn{2}{|c|}{$3.85(0.5716)$} & & \\
\hline $\begin{array}{l}\text { Sargan (score) } \\
\text { Basmann chi } 2(2 \\
\text { Instrumented: } 7 \\
\text { Instruments: Tc } \\
\text { Hansen's J chi2 } \\
\text { Instrumented: } \\
\text { Instruments: C } \\
\text { Note: } * \text {, **, and }\end{array}$ & $\begin{array}{l}\text { hi2 }(2)=4.268(p \\
\quad=4.029(p= \\
\text { bin's } q \\
\text { bin's } q \text { (3lags) } \\
\text { l4) }=11.631(p=0 \\
\text { obin's } q \\
\text { sh flow (3lags, lev lev } \\
* * *, \text { denote signific }\end{array}$ & $\begin{array}{l}\text { 6359) } \\
\text { erage ratio (3lags) } \\
\text { ince at } 10 \%, 5 \% \text {, }\end{array}$ & $\begin{array}{l}\text { rofit after tax }(3 l c \\
\text { nd } 1 \%\end{array}$ & sales (3lags) an & Tobin's q(3lags). \\
\hline
\end{tabular}

Source: Computed by the authors from the Data obtained from Companies' Annual Reports using STATA 12

\section{Investment-Cash Flow Sensitivity Results after Financial Crisis}

Table 4 presents the results of estimation of investment-cash flow sensitivity after the financial crisis. Employing Hausman specification test to determine the choice between fixed effect model and random effect model shows that the difference in the coefficients of fixed effect and random effect is systematic. This implies that only the fixed effect model are acceptable and can thus be interpreted. In the fixed effect model's results, investment is negatively and significantly sensitive to cash flow with coefficient of -0.231 . This implies firms' investments are less sensitive to their cash flow after the financial crisis. Tobin's q, leverage ratio and profit after tax have a negative effect on investment. However, it is only profit after tax that is statistically significant at the 5\% level. Sales positively and significantly determine investment. Specifically, an increase in sales by one unit will result in 0.296 increases in investment. 
The results from the Two Stage Least Square (2SLS) estimation in column 5 of Table 4 show that even though cash flow has a positive effect on investment, it is not statistically significant. This implies that cash flow does not really matter for investment. However, profit after tax and sales matter for investment as they are positively and significantly related to investment. Specifically, investment will rise by 0.373 and 0.113 if profit after tax and sales increase by one unit. Tobin's q and leverage ratio also have a positive effect on investment; they are however not statistically significant. Sargan and Basmann Chi2 test result values of 2.074 and 1.890 respectively, with p-value greater than $5 \%$ show that the instruments used are not over-identified.

The GMM estimation results in column 6 show that cash flow has a positive insignificant effect on investment. On the other hand, profit after tax and sales, as in 2SLS, have a positive and significant effect on investment. Suffice it to say that even though Tobin's q and leverage rate are positively related to investment, they are not statistically significant. Hansen's J Chi2 test value of 9.960 with the probability value greater than $5 \%$ shows that the instruments used are not over-identified.

Table 4: Investment-Cash flow Sensitivity after Financial Crisis

\begin{tabular}{|c|c|c|c|c|c|}
\hline Column 1 & Column 2 & Column 3 & Column 4 & Column 5 & Column 6 \\
\hline Variables & $\begin{array}{c}\text { OLSPA(Pooled } \\
\text { Analysis) }\end{array}$ & Panel with FE & Panel with RE & IV(2SLS)3L & IV (GMM) \\
\hline Constant & -0.000103 & -0.0000739 & -0.000166 & $-0.000233^{* * *}$ & -0.000092 \\
\hline Tobin's q & -0.0000146 & -0.0000627 & -0.0000243 & 0.0000274 & 0.00000948 \\
\hline Cash flow & 0.056 & $-0.231 * * *$ & 0.0210 & 0.0499 & 0.0980 \\
\hline Leverage ratio & 0.0000923 & -0.000172 & 0.0000916 & 0.0000778 & 0.0000232 \\
\hline Profit after tax & $0.383 * * *$ & $-0.359 * *$ & $0.264 * *$ & $0.373 * * *$ & $0.411 * *$ \\
\hline Sales & $0.085 * *$ & $0.296^{* * * *}$ & $0.131 * * *$ & $0.113 * * *$ & $0.070 * *$ \\
\hline R-Square & $0.6025(60.25 \%)$ & $0.0150(1.50 \%)$ & $0.5877(58.77 \%)$ & $0.6878(68.78 \%)$ & $0.6223(62.23 \%)$ \\
\hline F-Statistics & $20.91(0.0000)$ & $10.33(0.0000)$ & $63.85(0.0000)$ & $153.42(0.0000)$ & $272.49(0.0000)$ \\
\hline Hausman Test & & \multicolumn{2}{|c|}{$162.09(0.0000)$} & & \\
\hline \multicolumn{6}{|c|}{$\begin{array}{l}\text { Sargan (score) } \text { chi2 }(2)=2.074(p=0.3546) \\
\text { Basmann chi } 2(2)=1.890(p=0.3887) \\
\text { Instrumented: Tobin's } q \\
\text { Instruments: Tobin's } q(3 \text { lags }) \\
\text { Hansen's } J \text { chi2 } 2(9)=9.960(p=0.3537) \\
\text { Instrumented: Tobin's } q \\
\text { Instruments: Cash flow (3lags,) leverage ratio (3lags) profit after tax (3lags) sales (3lags) and Tobin's } q(3 \text { lags). } \\
\text { Note: } *, * *, \text { and } * * *, \text { denote significance at } 10 \%, 5 \%, \text { and } 1 \%\end{array}$} \\
\hline Source: Compu & by the authors $\mathrm{f}$ & the Data obtail & from Compan & Annual Reports & ing STATA 12 \\
\hline
\end{tabular}




\section{Conclusions and Policy Recommendations}

This study finds that the sources of financing are indispensable to firms' investment in Nigeria. The sources of financing firms' investment are, however, conditioned on the state of the economy. During the economy downturn such as the case of the recent global financial crisis, it is found that firms' investment solely depends on their internal fund (cash flow) while during normal economic condition firms could deploy less internal funds and more external funds to finance their investment. In specific terms, the study finds that firm's investment was highly sensitive to firm's cash flow during the financial crisis of 2008 and less sensitive to cash flow before and after the crisis. This may not be unconnected with the difficulties faced by firms in raising external funds in both the money and capital markets during the financial meltdown. Therefore, it becomes imperative for government to put relevant fiscal and monetary policies in place that can strengthen the financial sector to perform its role of providing loanable funds at reasonable cost as when needed by firms.

\section{NOTES}

${ }^{1}$ See Fazzari, Hubbard and Petersen 1998

${ }^{2}$ See Kaplan and Zingale, 1997 for expository explanation

${ }^{3}$ Other empirical findings that corroborated Fazzari et al findings are Allayannis and Mozumdar (2004), Fazzari, Hubbard, and Petersen (2000), Gilchrist and Himmelberg (1995), Hoshi, Kashyap, and Scharfstein(1991).

${ }^{4}$ Tobin's q represents the investment or growth opportunity measured by the ratio of market value of equity (market stock) to corporate net worth.

${ }^{5}$ Cash flow is measured by sum of earnings before interest, tax or operating income plus depreciation.

${ }^{6}$ Other control variables include profit after tax, sales as well as leverage ratio

\section{REFERENCES}

Adelegan, O. J., \& Ariyo, A. (2008). Capital market imperfections and corporate investment behaviour: a switching regression approach using panel data for Nigerian manufacturing firms. Journal of Money, Investment and Banking, ISSN 1450- 288X Issue 2 (2008) (C) Euro Journals Pub-

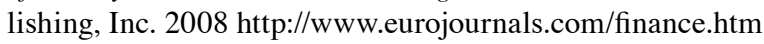

Adelegan, O. J. (2009). Investment, financial factor and cash flow from Nigerian panel data. Journal of African Development, Vol. 11, No. 1

Aftalion, A. (1909). La Réalité des surproductionsgénérales: essaid'unethéorie des crises généralesetpériodiques. Revue d'Economie Politique.

Almeida, H. \& Campello M. (2002). Financial constraints and investment-cash flow sensitivities: new research directions. Working paper, New York University and University of Illinois 
Almeida, H. \& Campello, M. (2007). Financial constraints, asset tangibility, and corporate investment. NBER Working Paper, No.12087

Almeida, H. Campello M, \& Galvao, A. (2010). Measurement error in investment equations. Review of Financial Studies 23, 3279-3328

Alti, A. (2003). How sensitive is investment to cash flow when financing is friction. The Journal of Finance, Vol. 58, No. 2.

Annabi, R. A., Djelassi, M., \& Hakimi, A. (2012) Financial constraints, information assymetry and Tunisian firm investment. Journal of Applied Finance and Banking, Vol.2, No. 4, pp. 103-116.

Arellano, M., \& Bond, S. (1991). Some tests of specification for panel data: monte carlo evidence and an application to employment equations. Review of Economic Studies 58, 277-297.

Baum, C. F. \& Thies, C. F. (1999). Q, cash flow and investment: an econometric critique. Review of Quantitative Financial and Accounting, Vol. 12, Issue 1, pp35-48

Bhagat, S. Moyen, N. \& Suh, I. (2006). Investment and internal funds of distressed firms. Journal of Corporate Finance, Vol. 11, Issue 3, pages 449-472

Bickerdike, C.F. (1914). A non-monetary cause of fluctuations in employment. Economic Journal, Vol. 24, No.95, pp. 357-370.

Biorn, E. (2000). Panel data with measurement errors: instrumental variables and GMM procedures combining levels and differences. Econometric Reviews 19, 391-424.

Blalock, G., Gertler, P. J. \& Levine, D. I. (2007). Financial constraints on investment in an emerging market crisis: an empirical investigation of foreign ownership. Center for International and Development Economic Research Working Paper Series, Business and Economic Research, UK Berkeley

Bond S. R. \& Soderbom, M. (2010). Conditional investment-cash flow sensitivities and financial constraints. Working Papers in Economics, No. 28

Brainard, W. C. \& Tobin, J. (1968). Pitfalls in financial model building. American Economic Review, Vol. 58, no. 2, 99---122.

Bushman, R. M. Smith, A. J. \& Zhang, X. F. (2011). Investment-cash flow sensitivities are really investment-investment sensitivities. Seminal Paper Presented at Carnegie Mellon University, Chinese University of Hong Kong, Emory University, INSEAD, Penn State University, Yale University, and the University of Toronto

Calomiris, C. W. Himmelberg, C. P. \& Wachtel, P. (1995). Commercial paper and corporate finance: a microeconomic perspective. Carnegie-Rochester Conference Series on Public Policy, vol. 42, pp. 203-50.

Campello, M. Graham, J. R. \& Harvey, C. R. (2009). The real effects of financial constraints: evidence from a financial crisis. NEBR Working Paper No. 15552.

Carpenter R. E. \& Guariglia, A. (2003). Cash flow, investment, and investment opportunities: new tests using UK Panel data. Discussion Paper in Economics, No.03/24, University of Nottingham.

Carpenter, R. E., Fazzari, S, M. \& Petersen, B. C. (1994). Inventory investment, internal-finance fluctuations, and the business cycle. Brookings Papers on Economic Activity, 2:1994, pp. 75-138.

Carver, T. N. (1903). The relation of abstinence to interest. Quarterly Journal of Economics, 1903, 18 (1), pp. 142-145.

Chirinko R. S. \& von Kalckreuth, U. (2002). Further evidence on the relationship between firm investment and financial status. Discussion Paper 28/02 Economic Research Centre of the Deutsche Bundesbank

Chirinko, R. S. \& Schaller, H. (1995). Why does liquidity matter in investment equations?. Journal of Money, Credit and Banking, vol. 27, pp. 527--48

Clark J. M. (1917). Business acceleration and the law of demand: a technical factor in economic cycles. Journal of Political Economy, vol. 25, pp. 217-35. 
Cleary, S., Povel P. \& Raith, M. (2007). The u-shaped investment curve: theory and evidence. Journal of Financial and Quantitative Analysis 42, 1-39.

Cleary, S. (1999). The relationship between firm investment and financial status. Journal of Finance, 673-692

D'Espallier, B. \& Lopez-Iturriaga F. (2009). On the negative relation between investment-cash flow sensitivities and cash-cash flow sensitivities. Faculty of Business and Economics, Department of Accountancy, Finance and Insurance (AFI)

Devereux, M. P. \& Schiantarelli, F. (1990). Investment, financial factors and cash flow from uk panel data." in g. hubbard, ed., Information, Capital Markets and Investment Chicago, IL: University of Chicago Press.

Drobetz W., Haller, R. Meier, I. and Tarhan, V. (2014). The impact of liquidity crisis on cash flow sensitivities. 26 ${ }^{\text {th }}$ Australasian Finance and Banking Conference 2013.

Duesenberry, J. S. (1958). Business cycle and economic growth. McGraw-Hill New York, pp. 49-85

EFInA, (2010). Financial Services Landscape in Nigeria. Full Report

Erickson, T., \& Whited, T. (2000). Measurement error and the relationship between investment and q. Journal of Political Economy, 108, 1027-1057

Fazzari, S.M. Hubbard R.G. \& Petersen, B.C. (1988). Financing constraints and corporate investment. Brookings Papers on Economic Activity, Vol. 1 pp. 141-195.

Gertler, M. (1992). Financial capacity and output fluctuations in the economic with multiperiod financial arrangements. Review of Economic Studies, Vol. LIX, pp. 455-472.

Gilchrist, S. \& Himmelberg, C. P. (1995). Evidence on the role of cash flow for investment. Journal of Monetary Economics, 36(3), pp. 541-72.

Hobdari, B. Jones, D. C. \& Mygind, N. (2009). Capital investment and determinants of financial constraints in Estonia. Economic Systems, Volume 33, Issue 4, pp. 344-359.

Hoshi, T. Kashyap, A. \& Scharfstein, D. (1991). Corporate structure, liquidity, and investment: evidence from Japanese industrial groups. Quarterly Journal of Economics, 106, 33-60.

Jiming, L. Chengqin, S. \& Zhao H. W. (2010). The impact of debt financial of firm investment behaviour: evidence from china. International Journal of Digital Content Technology and its Application, Vol. 4

Jorgenson, D. (1967). The theory of investment behaviour, in: determinants of investment behaviour", Universities---National Bureau Conference Series No. 18, Ed.: Ferber, R., Colombia University Press, New York.

Kaplan, S. \& Zingales, L. (1997). Do investment-cash flow sensitivities provide useful measures of financing constraints?. Quarterly Journal of Economics, 112, 169- 215

Keynes, J. M. (1936). The General Theory of Employment, Interest and Money. Macmillan

Khramov, V. (2012). Asymmetric effects of the financial crisis: collateral-based investment-cash flow sensitivity analysis. IMF Working Paper, WP/12/97.

Klein, L. R. (1958). The estimation of distributed lag. Econometrica, 26 pp. 553-565

Kozhan, R. \& Pal R. (2008). Firms' Investment under Financial Constraints: A European Area Investigation. Working Papers Series, (WP08-07)

La Rocca, M., Stagliano, R. \& Laguir, I. (2016). Long-term investment sensitivity to cashflow and financial crisis. Journal of Applied Economics Letter, Volume 23, Issue 6.

Lewellen, R. \& Lewellen, K. (2011). Investment and Cash flow: New Evidence. Journal of Multinational Financial Management, Vol. 21, Issue 2, pp. 69-88.

Marhfor, A. M'Zali B. \& Cosset, J. (2012). Firm's financing constraints and investment-cash flow sensitivity: evidence from country legal institutions. ACRN Journal of Finance and Risk Perspectives, Vol. 1, Issue 1, p. 50-66

Meyer, J.R. \& Kuh, E. (1957). The Investment Decision. Harvard University Press, Cambridge, MA 
Mizen P. \& Vermuelen P. (2005). Corporate investment and cashflow sensitivity: what drives the relationship? European Central Bank Working Paper Series, No. 485

Modigliani, F. \& Miller, M. H. (1958). The cost of capital, corporation finance, and the theory of investment. American Economic Review 48, 261-297.

Ng, S. \& Schaller, H. (1991). The risk spread and monetary policy transmission: evidence on the role of asymmetric information. Princeton University, Mimeo

Oliner, S. D. \& Rudebusch, G. D. (1992). Sources of the financing hierarchy for business investment. The Review of Economics and Statistics, Vol. LXXIV, no. 4, pp. 643-54.

Sembenelli, A., L. Schiantarelli, F. \& Sack, B.and, (1993). Firms' real and financial responses to business cycle shocks and to monetary tightening: evidence for large and small Italian companies. CERIS CMR Working Paper No. 5.

Samuelson, P. (1939a). Interaction between the multiplier analysis and the principle of acceleration. Review of Economics and Statistics, Vol. 21, no. 2, 75---78

Samuelson, P. (1939b). A Synthesis of the Principle of Acceleration and the Multiplier. Journal of Political Economy, Vol. 47, No. 6

Schaller, H. (1993). Asymmetric information, liquidity constraints, and Canadian investment. Canadian Journal of Economics, Vol. 26, pp. 552-74.

Whited, T. M. (1992). Debt, liquidity constraints, and corporate investment: evidence from panel data. Journal of Finance, Vol. 47 (September), pp. 1425-60. 